\title{
Modeling the activities of financial institutions in changing macroeconomic conditions as a stability factor of the economy
}

\author{
Ayur Ayurzanain*, and Oksana Darmaeva \\ East-Siberian state University of technology and management, Klyuchevskaya St. 40B, p. \\ 1, 670033 Ulan-Ude, Russia
}

\begin{abstract}
This article is devoted to the study of the activity of financial market institutions in modern conditions, the main feature of which is the constant change in the conditions of the institutional environment and macroeconomic stability. Scientists have proved the increasing importance of financial institutions in ensuring the economic growth of the economies of States in the XXI century. The authors consider and systematize the approaches of different authors and representatives of different directions of institutionalism and economic science to the definition of the role and essence of financial institutions. Also, the main conclusions about the impact of the global financial and economic crisis of 2008-2009 and sanctions of Western countries on the activities of the institutions of the Russian financial market in 2018 are formulated, based on the collection of statistical data, calculations are made and a model is formed, as a result of which a number of conclusions are obtained. As a result of calculations of the mathematical model made in the MS Excel program on the basis of statistical data of the Central Bank of Russia characterizing a condition of the financial market in 2008, 2009 and 2018 it is revealed that in economy of Russia there were considerable changes. The proposed model of assessing the institutional impact of financial institutions on economic growth as a practical tool can use a larger number of statistical indicators for calculations and obtaining more accurate data to solve more complex scientific and practical problems.
\end{abstract}

\section{Introduction}

The modern financial market is a very complex and multi-faceted system, in which the main element is formed institutions. the processes of digitalization and the intensive development of innovative technologies accelerate the processes of money exchange many times, offer new investment mechanisms, including those using electronic and cryptocurrency.

A number of significant institutional changes in the financial market have taken place in Russia over the past decade, and how effective they are for the current financial market system in the country remains an open question.

Macroeconomic instability, as a global phenomenon for the entire world economic system, is now seen as a challenge for any market, and the Russian financial market is no

${ }^{*}$ Corresponding author: ayurza9@yandex.ru 
exception. A number of economic sanctions, including in the financial sphere, directly affected Russia's financial institutions, which had to adapt to the new economic realities by implementing significant economic transformations, both at the state level and significant institutional changes on the ground.

This article attempts to give a qualitative assessment of the impact of financial institutions on economic growth, as a result of their activities within the system. However, at the same time, there is a need to systematize quantitative and qualitative indicators in order to be able to monitor, including control over the quality of implemented institutional changes in order to develop a balanced economic policy and maximize efficiency.

The beginning of the new century marked the growing role of financial institutions in the economy. Innovative technologies and high rates of technological development currently require additional development of investment institutions, which today, in order to ensure maximum efficiency, are intensively implementing significant structural and institutional changes.

The investment process in the economy largely contributes to the support of high rates of economic growth. Financial institutions play a key role in the implementation of investment processes in the economy, because they represent a multi-level system of contractual relations, a huge number of investment transactions that are associated with the distribution of a large number of assets both in national economies and around the world.

The very development of financial institutions in the most developed countries plays a key role today and largely ensures the high competitiveness of national economies.

Thus, it can be recognized that financial institutions are the most important factor of economic growth in modern conditions [1].

In Russia today there is a situation in which we can observe the underdevelopment of the financial market, low level of financial literacy of the population and institutional trust in financial institutions. In this case, it becomes a limiting factor of commodity-money exchange. The population simply does not know how to use the available money to make investments based on the use of financial instruments. At the same time, a number of crises and bankruptcies of banks have formed a consistently low level of institutional confidence in the financial sector as such and financial institutions in particular [2].

The institutional direction of economic theory considers the functioning of financial institutions from a different angle: from the point of view of the impact on socio-economic relations, the development of commodity-money and investment processes. Classical institutionalists (T. Veblen, J. Galbraith, J. Commons, and others) believed that institutions are the basis of any economic system, and they are constantly evolving through the implementation of institutional changes.

In turn, the process of institutional change was considered in the works of a new direction of economic thought - a new institutional economic theory, the main ideologists of which are O. Williamson, R. Coase, D. North, M. Olson, V. A. Schmidt, G. M. Hodgson, E. G. Furubotn and others.

Among Russian scientists in the field of institutional research include the following: L. I. Abalkin, R. I. Kapelyushnikov, Yaroslav Kuzminov, D. S. Lvov, V. I. Mayevsky, R. M. Nureev, V. A. naishul, A. N. Oleinik, V. V. Radaev, V. L. Tambovtsev, A.E. Shastitko, etc.

The aim of the study is to identify the features and trends of financial institutions in the context of economic development in changing macroeconomic conditions using the proposed author's model, which can be used to assess the state of the economy on quantitative statistical data on the activities of financial institutions (for example, such as Deposit, credit operations and investments in securities) [3]. 


\section{Theory}

The modern financial market is a very complex and multifaceted system, in which the main element is formed institutions. the processes of digitalization and the intensive development of innovative technologies accelerate the processes of money exchange many times, offer new investment mechanisms, including those using electronic and cryptocurrency.

A number of significant institutional changes in the financial market have taken place in Russia over the past decade, and how effective they are for the current financial market system in the country remains an open question.

Macroeconomic instability, as a global phenomenon for the entire world economic system, is now seen as a challenge for any market, and the Russian financial market is no exception. A number of economic sanctions, including in the financial sphere, directly affected Russia's financial institutions, which had to adapt to the new economic realities by implementing significant economic transformations, both at the state level and significant institutional changes on the ground.

This article attempts to give a qualitative assessment of the impact of financial institutions on economic growth, as a result of their activities within the system. However, at the same time, there is a need to systematize quantitative and qualitative indicators for the possibility of monitoring, including monitoring the quality of implemented institutional changes in order to develop a balanced economic policy and maximize efficiency.

In the study of approaches to the definition of a financial institution, it is very important to note that within the framework of the works of scientists from the institutional direction, the term «financial institution» is vague. There is no doubt that financial institutions should be classified as economic institutions allocated within the institutional framework. It should be noted that in the new institutional economic theory, with the actual identification of the concept of Institute, firm and organization; the activities of banking, investment, insurance and non-profit institutions are often considered on the example of specific relations mainly for the purpose of disclosing the category of transaction costs and analyzing the impact on the economy. The main views of scientists on the concept of a financial institution in the modern economy are presented in table 1.

Table 1. Concepts «financial institution» and «economic Institute» in the works of scientistsinstitutionalists.

\begin{tabular}{|l|l|}
\hline \multicolumn{1}{|c|}{ Author } & \multicolumn{1}{c|}{ The definition of a financial institution } \\
\hline D. North & $\begin{array}{l}\text { Formal economic institutions in the scientific literature are considered most often in the same } \\
\text { context with property rights, since they «establish property rights, that is, a bundle of rights to } \\
\text { use and receive income from property, and alienation of other persons from the use of property } \\
\text { or resources». }\end{array}$ \\
\hline $\begin{array}{l}\text { John. } \\
\text { Commons. }\end{array}$ & $\begin{array}{l}\text { Features of «financial capitalism» are manifested in the strengthening of the role of banks and } \\
\text { other financial institutions and in the formation of developed collective social groups - trade } \\
\text { unions, corporations and political parties. }\end{array}$ \\
\hline $\begin{array}{l}\text { W. J. } \\
\text { Samuels. }\end{array}$ & $\begin{array}{l}\text { Financial institutions include companies that provide financial services, markets, } \\
\text { intermediaries, that is, those institutions, by which the counterparty of the market realize they } \\
\text { have taken financial decisions. }\end{array}$ \\
\hline $\begin{array}{l}\text { V. V. Zotov, } \\
\text { V. F. } \\
\text { Presnyakov, } \\
\text { V. O. } \\
\text { Rosenthal }\end{array}$ & $\begin{array}{l}\text { Economic institutions are socially recognized functional and organizational forms of collective } \\
\text { economic activity, through which the system functions of the economy are realized. }\end{array}$ \\
\hline & $\begin{array}{l}\text { The institutional response to the costs of settlements has been the development of a system of } \\
\text { specialized units } \\
\text { within organizations, as well as independent organizations that perform an intermediary } \\
\text { function in the calculations. Such organizations have become banks. However, due to the } \\
\text { increase in the volume of operations and their frequency, further specialization was required. } \\
\text { Among the firms that provide net transaction services, or transaction services, the following } \\
\text { should be distinguished: Finance and real estate transactions, banking and insurance. }\end{array}$ \\
$\begin{array}{l}\text { A. E. } \\
\text { Shastitko }\end{array}$
\end{tabular}


Table 1. Continued

\begin{tabular}{|c|c|}
\hline $\begin{array}{l}\text { O. } \\
\text { Williamson }\end{array}$ & $\begin{array}{l}\text { The main purpose and result of the functioning of economic institutions of capitalism is to } \\
\text { minimize transaction costs... } \\
\text { Although the theory of transaction costs is applicable to the study of economic organizations of } \\
\text { all types, the focus is on the economic institutions of capitalism with a focus on firms, markets } \\
\text { and «relational» Contracting. Firms are a set of contractual relations. }\end{array}$ \\
\hline R. Coase & $\begin{array}{l}\text { Such institutions as the firm and the market make up the institutional structure of the economic } \\
\text { system... the Main purpose of economic institutions is to save on transaction costs and to } \\
\text { reduce risk, and the content is to unite individuals, each of which pursues its own economic } \\
\text { benefit. }\end{array}$ \\
\hline J. Hodgson & $\begin{array}{l}\text { The nature of modern financial institutions, state economic policy, case law clearly favors the } \\
\text { traditional firm. } \\
\text { The relationship between the financial and industrial sectors of the economy should also be } \\
\text { taken into account. The financial environment, including access to Finance and interest rates, } \\
\text { has an impact on any business. It can be proved that a stable financial environment focused on } \\
\text { long-term growth of the entire economy contributes to the creation of favorable conditions for } \\
\text { business and technological improvement. }\end{array}$ \\
\hline
\end{tabular}

It should be noted that the concept of a financial institution and its activities are directly related to the economic category of financial assets. Traditionally, the term «asset» refers to property owned by the constituent entities of the economy $[4,5]$.

The category of «financial asset» in the economy is defined as property presented in the form of financial documents, which record the rights and obligations of economic entities regarding cash payments. In addition to money, financial assets include securities and insurance instruments. The most detailed concept of the category of financial assets in the economy can be represented in the diagram (figure 1).

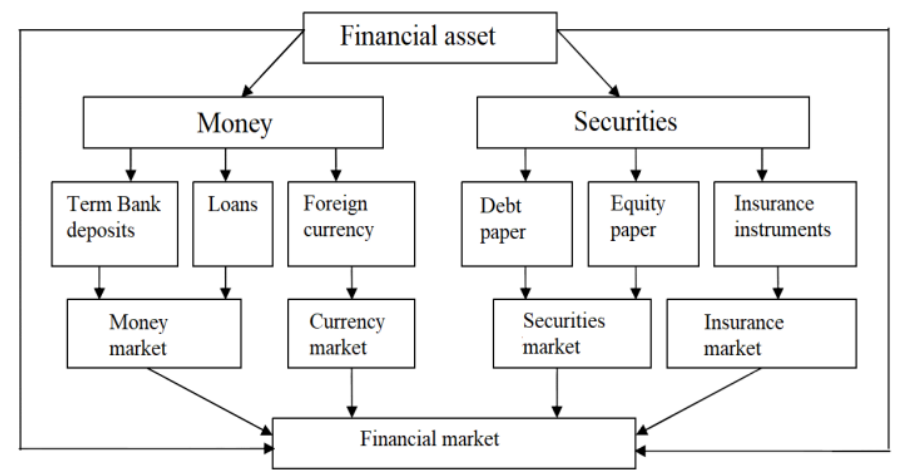

Fig. 1. Types of financial assets.

At the same time, the financial market is considered as a set of different mechanisms, institutions and economic relations through which financial assets are traded [7].

Taking into account the analysis of approaches to the definition of «Institute», «economic Institute», «financial institution» in the framework of the institutional direction, we have formed the following definition:

Financial institutions are a set of contractual relationships in the formation, distribution and use of financial assets in the economy. Banking, insurance, investment, exchange and non-profit financial institutions should be singled out. The fundamental element of the successful functioning of financial institutions in the economy is the institutional environment [6].

The objectives of the study require the gradual disclosure of the basic categories of institutional economy, among which the most important are the concept of transactions, transaction costs and the transaction sector in the economy. The formation of the transaction 
sector in the modern economy is largely carried out at the expense of transaction services provided by financial institutions [8].

\section{Data and methods}

The basis for the formation of the theoretical prerequisites of this study is a new institutional economic theory, which today offers the necessary tools to solve the questions and problems faced by modern researchers in the field of the functioning of market institutions, one of which is financial institutions.

Today, we can refer financial institutions to the transactional sector of the economy, on which the processes of commodity-money exchange as a basic element of the functioning of the entire system largely depend.

For the tasks of the study, it is necessary to form a certain universal model, which can be formed on the basis of quantitative indicators in order to determine the qualitative state of the functioning of market institutions.

The tools developed in the framework of this study offer a comparison of the resulting market conditions in order to analyze the impact of the institutions of this market on economic growth, which is the main resulting indicator of the market system.

The formation of a mathematical model based on the possibility of simultaneous accounting for an unlimited number of indicators provides an opportunity not only to quantify each indicator of the system, but also to give a short-term forecast of its development, which makes it possible to take into account an additional characteristic-trends.

The next important aspect of the proposed model of the influence of financial institutions on economic growth (in this case) is the ability to track the qualitative state of the market, financial market or other, in which the functioning of the analyzed institutions takes place.

In general, we can say that the proposed model is indicative, a gradual deterioration of macroeconomic indicators, along with a negative trend and an increase in macroeconomic instability, can act as a forecast for the upcoming crisis of the economy or its individual sectors.

The selection of quantitative indicators and the level of their significance is a key component and issue in the formation of this model. To simplify mathematical calculations, we propose to use a model based on four basic indicators of the system of banking institutions, which are regularly monitored by the Central Bank of the Russian Federation.

The tools developed in the framework of this study offer a comparison of the resulting market conditions in order to analyze the impact of the institutions of this market on economic growth, which is the main resulting indicator of the market system.

The basis for the formation of the theoretical prerequisites of this study is the new institutional economic theory, which today offers the necessary tools to solve the questions and problems posed by modern researchers in the field of the functioning of market institutions, one of which is financial institutions.

Financial institutions today can be attributed to the transactional sector of the economy, on which the processes of commodity-money exchange as a basic element of the functioning of the entire system largely depend.

For the tasks of the study, it is necessary to form a certain universal model, which can be formed on the basis of quantitative indicators in order to determine the qualitative state of the functioning of market institutions.

To perform calculations of the model for assessing the institutional impact of financial institutions on economic growth, there are two calculated parameters necessary for the construction of a matrix model in a two-dimensional coordinate system:

1) $\mathrm{k}$ - the share of the average statistical indicator of the financial institution in the total volume of statistical indicators during the analyzed period. 
For each statistic parameter $\mathrm{k}$ is calculated by the formula:

$$
\mathrm{ki}=\mathrm{yi} / \mathrm{y} 0 * 100 \%
$$

where $\mathrm{y} 0$ is the average volume of the indicator in monetary terms for the analyzed period; yi is the total volume of the indicator for the year.

2) $t$ - the contribution of the trend of each indicator to the change in the total trend is calculated for each indicator according to the formula:

$$
\mathrm{ti}=\mathrm{ai} / \mathrm{a} 0 * 100 \%
$$

where ai is the trend coefficient of the $\mathrm{i}$-th indicator during the analyzed period; $\mathrm{a} 0$ is the trend coefficient of the total indicator (the sum of private statistical indicators) for the analyzed period.

According to our model, based on the results, we can distinguish four basic states of the financial sector of the economy, on the basis of which the contribution of financial institutions to economic growth is estimated.

1) the state of economic growth - this state is characterized by positive trends in most of the most capital-intensive indicators of financial institutions in the analyzed period.

2) inertial development - this state can be characterized as a temporary uncertainty and reaction time to significant institutional changes or the negative impact of macroeconomic conditions. at the same time, this condition is characterized by multidirectional trends in the basic performance indicators of financial institutions during the analyzed period.

3) Economic instability - this state assumes a multidirectional growth trends of economic indicators of financial institutions, with the largest in quantitative terms indicators have a negative trend in the analyzed period;

4) Crisis economy or economic recession - this state is characterized mainly by negative trends in the growth of economic indicators of financial institutions in the analyzed period.

Thus, these estimated indices $\mathrm{ki}$ and ti are data to determine the coordinates of points when building a graphical model, which allows us to trace the resulting impact of institutional change and outcome that is possible in the framework of the proposed model (economic growth, slow economic development, unstable economy or the crisis economy) [9].

The model of assessing the institutional impact of financial institutions on economic growth allows us to trace and identify through which transactions in the transaction sector we have a particular state of the financial system of the state. The coordinate system is divided into 4 conditional quadrants, which characterize economic indicators based on quantitative characteristics and growth trends. 


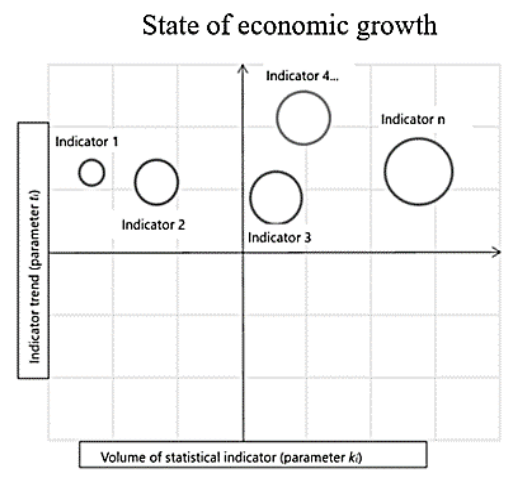

Unstable economy

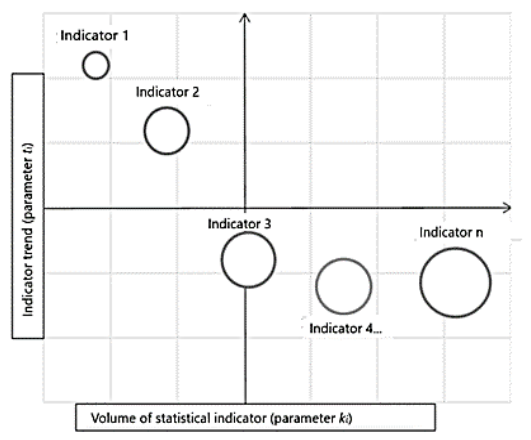

Inertial development of the economy

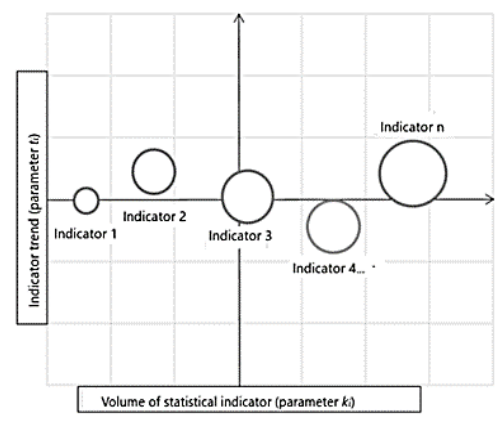

Economic crisis

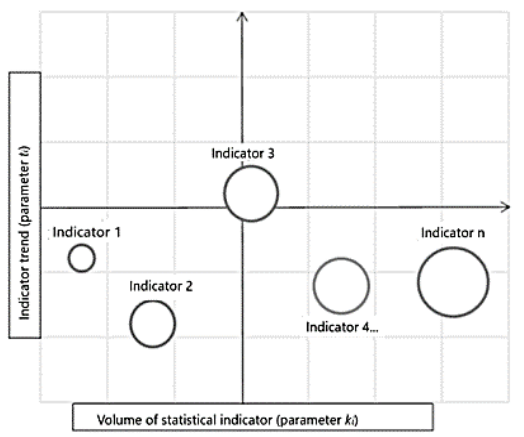

Fig. 2. Graphical representation of the results of the model for assessing the institutional impact of financial institutions on economic growth.

Thus, the indicators of this quadrant will have a positive impact on the final result, and with a large number of indicators in this quadrant, we will have a state of economic growth, according to the conditions of our proposed model.

In the second quadrant of the coordinate system, we have indicators of the transaction sector of the financial market with low quantitative characteristics, that is, in this quadrant, indicators with the lowest result are grouped.

These indicators have a minimal contribution to the development of the economy and have a minimal impact on economic growth, while with a large number of indicators in this quadrant, we will have a situation of inertial development.

In the third quadrant, economic indicators in the trade sector have negative growth trends and relatively low quantitative characteristics. These economic indicators make the least contribution to the formation of the final economic result. Therefore, there are a large number of indicators in this quadrant, and we will be in an unstable economic state.

In the fourth quadrant, there are economic indicators of the trade sector with relatively low quantitative characteristics, but high growth trends. These economic indicators make the least contribution to the formation of the final economic result.

\section{Model}

Based on the results of empirical statistics of the Central Bank of the Russian Federation, it is possible to construct a matrix model of the impact of financial institutions on economic growth for the period that is characterized by the most serious consequences for economic growth in terms of economic instability, we are talking about the period from 2008 to 2010. 
Table 2. Performance indicators of financial institutions in 2009, billion RUB.

\begin{tabular}{|c|c|c|c|c|c|c|c|c|c|c|c|c|}
\hline $\begin{array}{l}\text { Recor } \\
\text { d\Mon } \\
\text { th } \\
\end{array}$ & Jan & Feb & Mar & Apr & May & Jun & Jul & Aug & Sept & Oct & Nov & Dec \\
\hline $\begin{array}{l}\text { Loans } \\
\text { to } \\
\text { organi } \\
\text { zations }\end{array}$ & $\begin{array}{l}128 \\
44 \\
854\end{array}$ & $\begin{array}{l}137 \\
51 \\
695\end{array}$ & $\begin{array}{l}136 \\
83 \\
045\end{array}$ & $\begin{array}{l}134 \\
68 \\
452\end{array}$ & $\begin{array}{l}135 \\
11 \\
745\end{array}$ & $\begin{array}{l}133 \\
247 \\
45\end{array}$ & $\begin{array}{l}131 \\
77 \\
962\end{array}$ & $\begin{array}{l}131 \\
29 \\
456\end{array}$ & $\begin{array}{l}131 \\
27 \\
124\end{array}$ & $\begin{array}{l}130 \\
479 \\
63\end{array}$ & $\begin{array}{l}129 \\
73 \\
962\end{array}$ & $\begin{array}{l}130 \\
14 \\
745\end{array}$ \\
\hline $\begin{array}{l}\text { Loans } \\
\text { to } \\
\text { individ } \\
\text { uals }\end{array}$ & $\begin{array}{l}401 \\
7 \\
596\end{array}$ & $\begin{array}{l}403 \\
7 \\
547\end{array}$ & $\begin{array}{l}397 \\
1 \\
964\end{array}$ & $\begin{array}{l}387 \\
2 \\
595\end{array}$ & $\begin{array}{l}381 \\
1 \\
567\end{array}$ & $\begin{array}{l}373 \\
8 \\
786\end{array}$ & $\begin{array}{l}369 \\
8 \\
452\end{array}$ & $\begin{array}{l}368 \\
2 \\
458\end{array}$ & $\begin{array}{l}366 \\
0 \\
452\end{array}$ & $\begin{array}{l}361 \\
9 \\
956\end{array}$ & $\begin{array}{l}359 \\
3 \\
458\end{array}$ & $\begin{array}{l}358 \\
6 \\
965\end{array}$ \\
\hline $\begin{array}{l}\text { Interba } \\
\text { nk } \\
\text { credit }\end{array}$ & $\begin{array}{l}250 \\
1 \\
478 \\
\end{array}$ & $\begin{array}{l}286 \\
4 \\
962 \\
\end{array}$ & $\begin{array}{l}269 \\
0 \\
785 \\
\end{array}$ & $\begin{array}{l}266 \\
5 \\
962 \\
\end{array}$ & $\begin{array}{l}244 \\
6 \\
892 \\
\end{array}$ & $\begin{array}{l}231 \\
4 \\
487 \\
\end{array}$ & $\begin{array}{l}237 \\
7 \\
566 \\
\end{array}$ & $\begin{array}{l}280 \\
1 \\
963 \\
\end{array}$ & $\begin{array}{l}300 \\
9 \\
789 \\
\end{array}$ & $\begin{array}{l}290 \\
8 \\
745 \\
\end{array}$ & $\begin{array}{l}263 \\
9 \\
965 \\
\end{array}$ & $\begin{array}{l}282 \\
3 \\
874 \\
\end{array}$ \\
\hline $\begin{array}{l}\text { Volum } \\
\text { e of } \\
\text { invest } \\
\text { ments } \\
\text { in } \\
\text { securiti } \\
\text { es }\end{array}$ & $\begin{array}{l}585 \\
962\end{array}$ & $\begin{array}{l}586 \\
964\end{array}$ & $\begin{array}{l}821 \\
964\end{array}$ & $\begin{array}{l}848 \\
745\end{array}$ & $\begin{array}{l}819 \\
581\end{array}$ & $\begin{array}{l}860 \\
015\end{array}$ & $\begin{array}{l}859 \\
962\end{array}$ & $\begin{array}{l}894 \\
852\end{array}$ & $\begin{array}{l}920 \\
853\end{array}$ & $\begin{array}{l}994 \\
045\end{array}$ & $\begin{array}{l}107 \\
0 \\
758\end{array}$ & $\begin{array}{l}123 \\
4 \\
364\end{array}$ \\
\hline $\begin{array}{l}\text { TOTA } \\
\text { L }\end{array}$ & $\begin{array}{l}19 \\
949 \\
890\end{array}$ & $\begin{array}{l}21 \\
241 \\
168\end{array}$ & $\begin{array}{l}21 \\
167 \\
758\end{array}$ & $\begin{array}{l}20 \\
855 \\
754\end{array}$ & $\begin{array}{l}\mathbf{2 0} \\
\mathbf{5 8 9} \\
\mathbf{7 8 5}\end{array}$ & $\begin{array}{l}20 \\
238 \\
033\end{array}$ & $\begin{array}{l}20 \\
113 \\
942\end{array}$ & $\begin{array}{l}\mathbf{2 0} \\
508 \\
729\end{array}$ & $\begin{array}{l}20 \\
718 \\
218\end{array}$ & $\begin{array}{l}20 \\
570 \\
709\end{array}$ & $\begin{array}{l}20 \\
278 \\
143\end{array}$ & $\begin{array}{l}20 \\
659 \\
948\end{array}$ \\
\hline
\end{tabular}

The analysis of the activities of financial institutions was carried out on a number of parameters and quantitative data, among which the entire model was built on four grouped parameters:

1) loans to organizations;

2) loans to individuals;

3) interbank loans;

4) the volume of investments in securities.

Table 3. Performance indicators of financial institutions in 2008, trln. RUB.

\begin{tabular}{|c|c|c|c|c|c|c|c|c|c|c|c|c|}
\hline $\begin{array}{c}\text { Recor } \\
d \backslash \text { Mon } \\
\text { th }\end{array}$ & Jan & Feb & Mar & Apr & May & Jun & Jul & Aug & Sept & Oct & Nov & Dec \\
\hline $\begin{array}{l}\text { Loans } \\
\text { to } \\
\text { organi } \\
\text { zations }\end{array}$ & $\begin{array}{l}873 \\
1 \\
215\end{array}$ & $\begin{array}{l}100 \\
29 \\
412\end{array}$ & $\begin{array}{l}102 \\
29 \\
451\end{array}$ & $\begin{array}{l}106 \\
07 \\
745\end{array}$ & $\begin{array}{l}5411 \\
0 \\
945\end{array}$ & $\begin{array}{l}112 \\
45 \\
748\end{array}$ & $\begin{array}{l}115 \\
48 \\
654\end{array}$ & $\begin{array}{l}118 \\
404 \\
51\end{array}$ & $\begin{array}{l}122 \\
13 \\
451\end{array}$ & $\begin{array}{l}124 \\
19 \\
548\end{array}$ & $\begin{array}{l}126 \\
30 \\
748\end{array}$ & $\begin{array}{l}127 \\
33 \\
985\end{array}$ \\
\hline $\begin{array}{l}\text { Loans } \\
\text { to } \\
\text { individ } \\
\text { uals }\end{array}$ & $\begin{array}{l}324 \\
2 \\
124\end{array}$ & $\begin{array}{l}3 \\
0123 \\
21\end{array}$ & $\begin{array}{l}3 \\
0925 \\
42\end{array}$ & $\begin{array}{l}319 \\
9 \\
874\end{array}$ & $\begin{array}{l}3 \\
3484 \\
63\end{array}$ & $\begin{array}{l}346 \\
5 \\
954\end{array}$ & $\begin{array}{l}359 \\
0 \\
985\end{array}$ & $\begin{array}{l}373 \\
9 \\
748\end{array}$ & $\begin{array}{l}389 \\
0 \\
478\end{array}$ & $\begin{array}{l}401 \\
8 \\
748\end{array}$ & $\begin{array}{l}408 \\
3 \\
654\end{array}$ & $\begin{array}{l}405 \\
5 \\
748\end{array}$ \\
\hline $\begin{array}{l}\text { Interba } \\
\text { nk } \\
\text { credit }\end{array}$ & $\begin{array}{l}818 \\
541\end{array}$ & $\begin{array}{l}1 \\
5106 \\
58 \\
\end{array}$ & $\begin{array}{l}1 \\
7924 \\
32 \\
\end{array}$ & $\begin{array}{l}192 \\
2 \\
214 \\
\end{array}$ & $\begin{array}{l}182 \\
1 \\
451 \\
\end{array}$ & $\begin{array}{l}188 \\
8 \\
456 \\
\end{array}$ & $\begin{array}{l}180 \\
2 \\
548 \\
\end{array}$ & $\begin{array}{l}176 \\
3 \\
548 \\
\end{array}$ & $\begin{array}{l}193 \\
7 \\
984 \\
\end{array}$ & $\begin{array}{l}217 \\
0 \\
541 \\
\end{array}$ & $\begin{array}{l}238 \\
0 \\
987 \\
\end{array}$ & $\begin{array}{l}251 \\
7 \\
547 \\
\end{array}$ \\
\hline $\begin{array}{l}\text { Volum } \\
\text { e of } \\
\text { invest } \\
\text { ments } \\
\text { in } \\
\text { securiti } \\
\text { es }\end{array}$ & $\begin{array}{l}124 \\
7 \\
648\end{array}$ & $\begin{array}{l}113 \\
5 \\
789\end{array}$ & $\begin{array}{l}1 \\
0015 \\
12\end{array}$ & $\begin{array}{l}904 \\
562\end{array}$ & $\begin{array}{l}923 \\
412\end{array}$ & $\begin{array}{l}979 \\
324\end{array}$ & $\begin{array}{l}102 \\
3 \\
748\end{array}$ & $\begin{array}{l}998 \\
654\end{array}$ & $\begin{array}{l}906 \\
654\end{array}$ & $\begin{array}{l}887 \\
658\end{array}$ & $\begin{array}{l}810 \\
213\end{array}$ & $\begin{array}{l}834 \\
748\end{array}$ \\
\hline $\begin{array}{l}\text { TOTA } \\
\text { L }\end{array}$ & $\begin{array}{l}14 \\
039 \\
528 \\
\end{array}$ & $\begin{array}{l}15 \\
688 \\
180\end{array}$ & $\begin{array}{l}16 \\
115 \\
937\end{array}$ & $\begin{array}{l}16 \\
634 \\
395\end{array}$ & $\begin{array}{l}60 \\
204 \\
271\end{array}$ & $\begin{array}{l}17 \\
579 \\
482\end{array}$ & $\begin{array}{l}17 \\
965 \\
935\end{array}$ & $\begin{array}{l}18 \\
342 \\
401\end{array}$ & $\begin{array}{l}18 \\
948 \\
567\end{array}$ & $\begin{array}{l}19 \\
496 \\
495\end{array}$ & $\begin{array}{l}19 \\
905 \\
602\end{array}$ & $\begin{array}{l}20 \\
142 \\
028\end{array}$ \\
\hline
\end{tabular}


At the next stage, we proceed to build a graphical model and calculate the linear trend equations for each of the presented indicators, as shown in Figure 3.
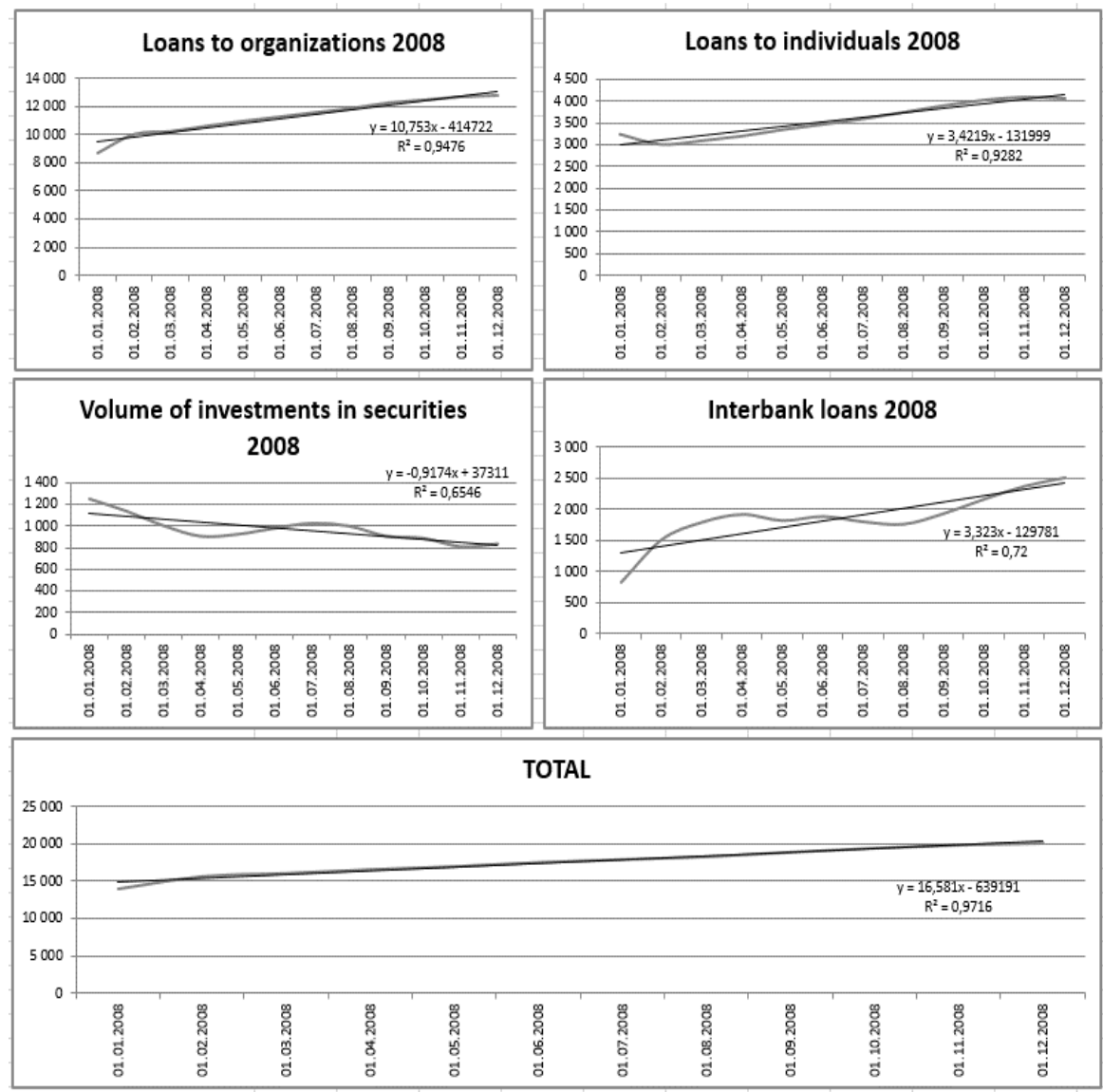

Fig. 3 Dynamics and linear trends in a number of indicators of banking institutions of the Russian Federation, 2008. 

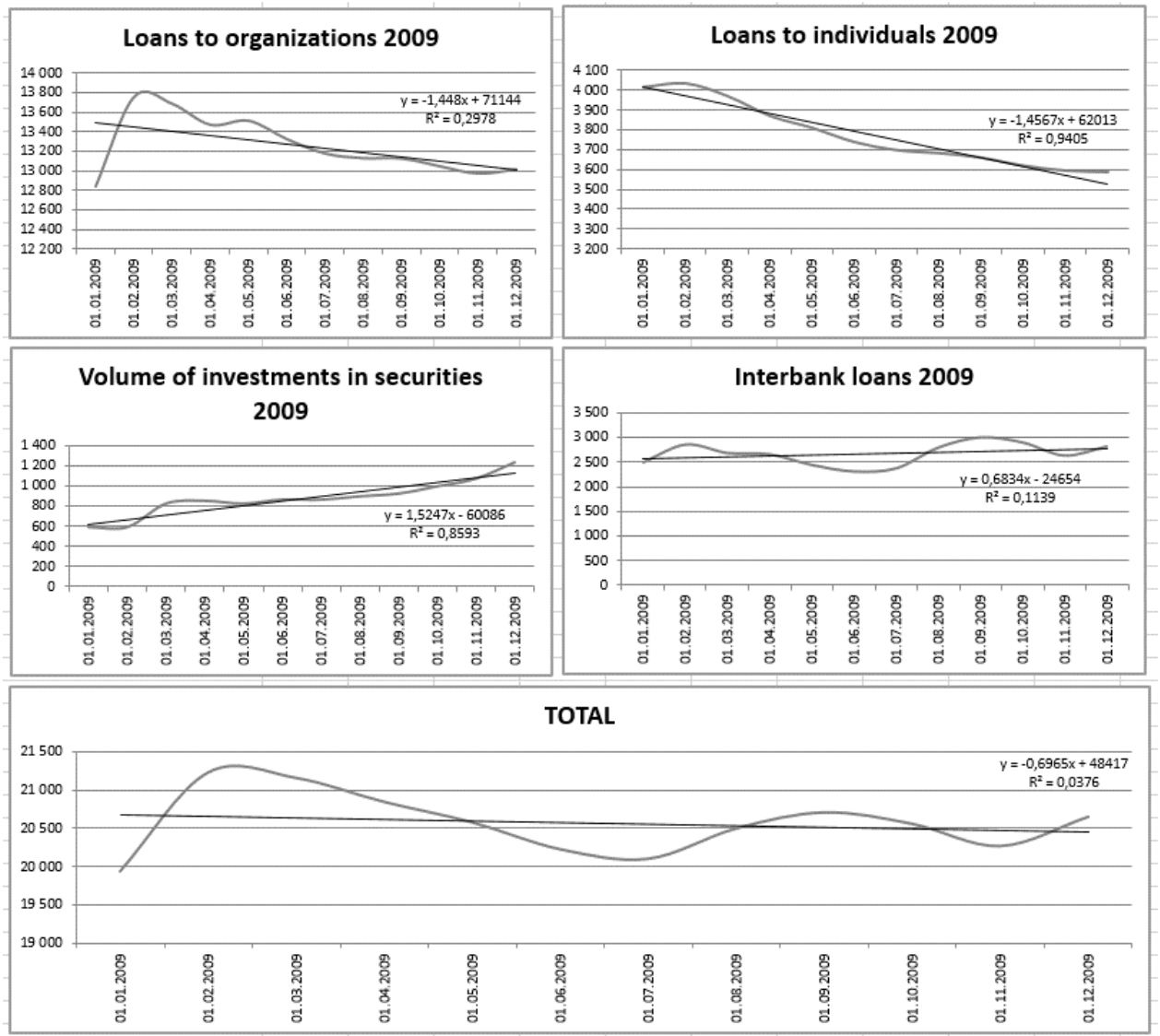

Fig. 4 Dynamics and linear trends in a number of indicators of banking institutions of the Russian Federation, 2009.

The calculation of the linear trend is important and necessary for taking into account the trends of the indicator in the reporting year and constructing points in a two-dimensional coordinate system in order to determine the structure of transaction services of the Russian financial market. Identification of crisis phenomena and trends in the functioning of this sector of the economy.

Table 4. Calculation of indicators Ki and Ti for model construction, 2008.

\begin{tabular}{|c|c|c|c|c|c|}
\hline Record $\backslash$ Month & $\begin{array}{c}\text { Total } \\
\text { annual } \\
\text { average, } \\
\text { billion. } \\
\text { RUB }\end{array}$ & Coefficient Ai & $\begin{array}{c}\text { Coefficient } \\
\text { Ao }\end{array}$ & $\begin{array}{c}\mathbf{K i}=\mathbf{Y i} \\
/ \mathbf{Y 0} \% \\
\mathbf{1 0 0 \%} \\
\text { (abscissa) }\end{array}$ & $\begin{array}{c}\mathbf{T i}=\mathbf{A i} \\
/ \mathbf{A}_{\text {об̆ }} * \\
100 \% \text { (axis } \\
\text { of ordinates) }\end{array}$ \\
\hline $\begin{array}{ll}\begin{array}{l}\text { Loans } \\
\text { organizations }\end{array} & \text { to }\end{array}$ & 11264145 & 327929 & 505632 & 63,8 & 64,9 \\
\hline $\begin{array}{ll}\text { Loans } & \text { to } \\
\text { individuals } & \end{array}$ & 3560458 & 104289 & & 20,2 & 20,6 \\
\hline Interbank credit & 1859784 & 101358 & & 10,5 & 20,0 \\
\hline $\begin{array}{ll}\text { Volume } & \text { of } \\
\text { investments } & \text { in } \\
\text { securities } & \\
\end{array}$ & 970052 & -27944 & & 5,5 & $-5,5$ \\
\hline TOTAL & 17654439 & Agen $=\mathbf{5 0 5 6 3 3}$ & & 100,0 & 100,0 \\
\hline
\end{tabular}


In order for the necessary values to be compared most correctly, it is necessary to adjust the value of each indicator by the amount of inflation of the analyzed period.

Table 5. Calculation of indicators Ki and Ti for model construction, 2009.

\begin{tabular}{|c|c|c|c|c|c|}
\hline Record $\backslash$ Month & $\begin{array}{c}\text { Total } \\
\text { average } \\
\text { for the } \\
\text { year with } \\
\text { inflation } \\
8.8 \%, \\
\text { billion. } \\
\text { RUB }\end{array}$ & $\mathbf{A i}$ & $\begin{array}{c}\text { Coefficient } \\
\text { Ao }\end{array}$ & $\begin{array}{c}\mathbf{K i}=\mathbf{Y} \mathbf{i} \\
/ \mathbf{Y 0} * \\
100 \% \\
\text { (abscissa) }\end{array}$ & $\begin{array}{l}\mathrm{Ti}=\mathbf{A i} / \mathbf{A}_{0 \sigma \tilde{m}} \\
* 100 \% \text { (axis } \\
\text { of ordinates) }\end{array}$ \\
\hline $\begin{array}{ll}\text { Loans } & \text { to } \\
\text { organizations } & \end{array}$ & 12088457 & -43937 & 505632 & 64,4 & $-207,0$ \\
\hline $\begin{array}{ll}\text { Loans } & \text { to } \\
\text { individuals }\end{array}$ & 3442879 & -44357 & & 18,3 & $-208,9$ \\
\hline Interbank credit & 2435412 & 20604 & & 13,0 & 97,1 \\
\hline $\begin{array}{ll}\text { Volume } & \text { of } \\
\text { investments } & \text { in } \\
\text { securities } & \end{array}$ & 797652 & 46461 & & 4,2 & 218,9 \\
\hline TOTAL & 18764400 & Agen $=21229$ & & 100,0 & $-100,0$ \\
\hline
\end{tabular}

Based on the obtained values of the key parameters $\mathrm{Ri}$ and Ti, a matrix model of 2 analysis cycles is constructed and changes are tracked. The starting point is determined based on the average value of the parameters $\mathrm{Ki}$ and $\mathrm{Ti}$ (Figure 5). In this case, the volume of the ball in Figure 5 is equal to the average value of the indicator for the reporting period, also expressed in millions of rubles in the data name of each indicator.

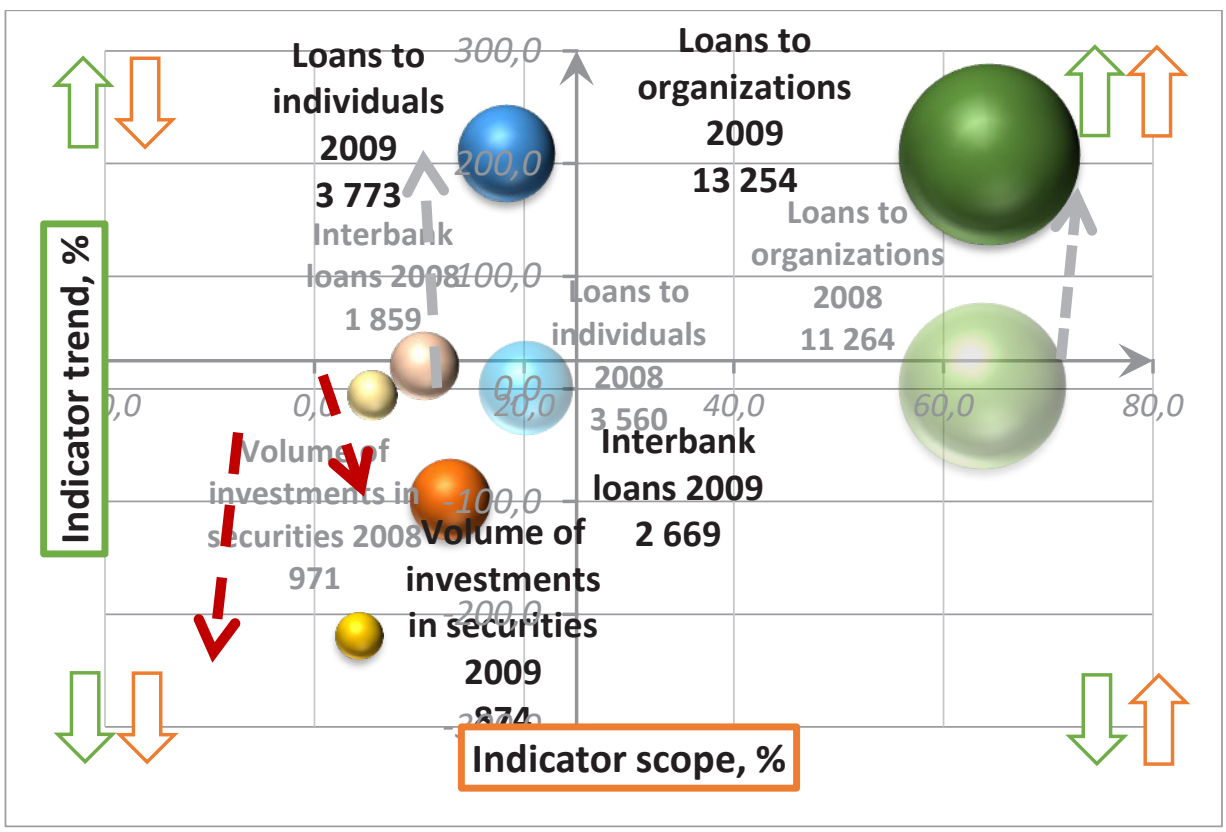

Fig. 5. Model for assessing the institutional impact of financial market institutions on economic growth, 2008-2009.

Consider the situation in the financial sector on the basis of the proposed model in 2018 and assess the situation in the Russian economy at the moment. After all, experts now largely 
disagree on how significant the impact of Western sanctions on the financial sector of the country and the economy of the Russian Federation as a whole.

Table 6. Performance indicators of financial institutions in 2018, trln. RUB.

\begin{tabular}{|c|c|c|c|c|c|c|c|c|c|c|c|c|}
\hline $\begin{array}{c}\text { Recor } \\
\text { d\Mon } \\
\text { th }\end{array}$ & Jan & Feb & Mar & Apr & May & Jun & Jul & Aug & Sept & Oct & Nov & Dec \\
\hline $\begin{array}{l}\text { Loans } \\
\text { to } \\
\text { organi } \\
\text { zations }\end{array}$ & $\begin{array}{l}3019 \\
3745\end{array}$ & $\begin{array}{c}30 \\
296 \\
875\end{array}$ & $\begin{array}{l}3018 \\
1752\end{array}$ & $\begin{array}{l}3062 \\
7754\end{array}$ & $\begin{array}{l}3143 \\
9965\end{array}$ & $\begin{array}{l}3128 \\
7856\end{array}$ & $\begin{array}{l}3139 \\
8748\end{array}$ & $\begin{array}{l}3159 \\
1741\end{array}$ & $\begin{array}{l}3268 \\
4758\end{array}$ & $\begin{array}{l}3289 \\
1748\end{array}$ & $\begin{array}{l}3298 \\
6741\end{array}$ & $\begin{array}{l}3307 \\
7789\end{array}$ \\
\hline $\begin{array}{c}\text { Loans } \\
\text { to } \\
\text { individ } \\
\text { uals }\end{array}$ & $\begin{array}{c}12 \\
174 \\
968\end{array}$ & $\begin{array}{c}12 \\
261 \\
963\end{array}$ & $\begin{array}{l}1237 \\
1641\end{array}$ & $\begin{array}{l}1257 \\
2632\end{array}$ & $\begin{array}{l}1280 \\
1546\end{array}$ & $\begin{array}{l}1305 \\
6789\end{array}$ & $\begin{array}{l}1329 \\
6789\end{array}$ & $\begin{array}{l}1356 \\
1963\end{array}$ & $\begin{array}{l}1389 \\
3741\end{array}$ & $\begin{array}{l}1417 \\
3978\end{array}$ & $\begin{array}{l}1441 \\
6963\end{array}$ & $\begin{array}{l}1473 \\
4741\end{array}$ \\
\hline $\begin{array}{c}\text { Interba } \\
\text { nk } \\
\text { credit }\end{array}$ & $\begin{array}{c}8070 \\
748\end{array}$ & $\begin{array}{c}6635 \\
741\end{array}$ & $\begin{array}{c}6448 \\
741\end{array}$ & $\begin{array}{c}5275 \\
741\end{array}$ & $\begin{array}{c}5947 \\
963\end{array}$ & $\begin{array}{c}5335 \\
748\end{array}$ & $\begin{array}{c}5649 \\
165\end{array}$ & $\begin{array}{c}5407 \\
745\end{array}$ & $\begin{array}{c}5861 \\
963\end{array}$ & $\begin{array}{c}5942 \\
784\end{array}$ & $\begin{array}{c}6522 \\
748\end{array}$ & $\begin{array}{c}7 \\
174 \\
325 \\
\end{array}$ \\
\hline $\begin{array}{l}\text { Volum } \\
\text { e of } \\
\text { invest } \\
\text { ments } \\
\text { in } \\
\text { securiti } \\
\text { es }\end{array}$ & $\begin{array}{c}9 \\
947 \\
963\end{array}$ & $\begin{array}{c}9 \\
977 \\
962\end{array}$ & $\begin{array}{c}10 \\
031 \\
368\end{array}$ & $\begin{array}{c}10 \\
433 \\
785\end{array}$ & $\begin{array}{c}10 \\
507 \\
741\end{array}$ & $\begin{array}{c}10 \\
665 \\
963\end{array}$ & $\begin{array}{c}10 \\
691 \\
788\end{array}$ & $\begin{array}{c}10 \\
845 \\
985\end{array}$ & $\begin{array}{c}10 \\
879 \\
478\end{array}$ & $\begin{array}{c}10 \\
836 \\
963\end{array}$ & $\begin{array}{c}10 \\
691 \\
894\end{array}$ & $\begin{array}{c}11 \\
009 \\
854\end{array}$ \\
\hline $\begin{array}{c}\text { TOTA } \\
\text { L }\end{array}$ & $\begin{array}{c}60 \\
387 \\
424\end{array}$ & $\begin{array}{c}59 \\
172 \\
541\end{array}$ & $\begin{array}{c}59 \\
033 \\
502\end{array}$ & $\begin{array}{c}58 \\
909 \\
912\end{array}$ & $\begin{array}{c}60 \\
697 \\
215\end{array}$ & $\begin{array}{c}60 \\
346 \\
356\end{array}$ & $\begin{array}{c}61 \\
036 \\
490\end{array}$ & $\begin{array}{c}61 \\
407 \\
434\end{array}$ & $\begin{array}{c}63 \\
319 \\
940\end{array}$ & $\begin{array}{c}63 \\
845 \\
473\end{array}$ & $\begin{array}{c}64 \\
618 \\
346\end{array}$ & $\begin{array}{c}65 \\
996 \\
709\end{array}$ \\
\hline
\end{tabular}

Based on the generated data and the calculated values of the basic indicators, the next step is to build a graphical model and calculate the linear trend equation for each indicator.The resulting trend equations and the dynamics of indicators will be reflected in the graphs below. 

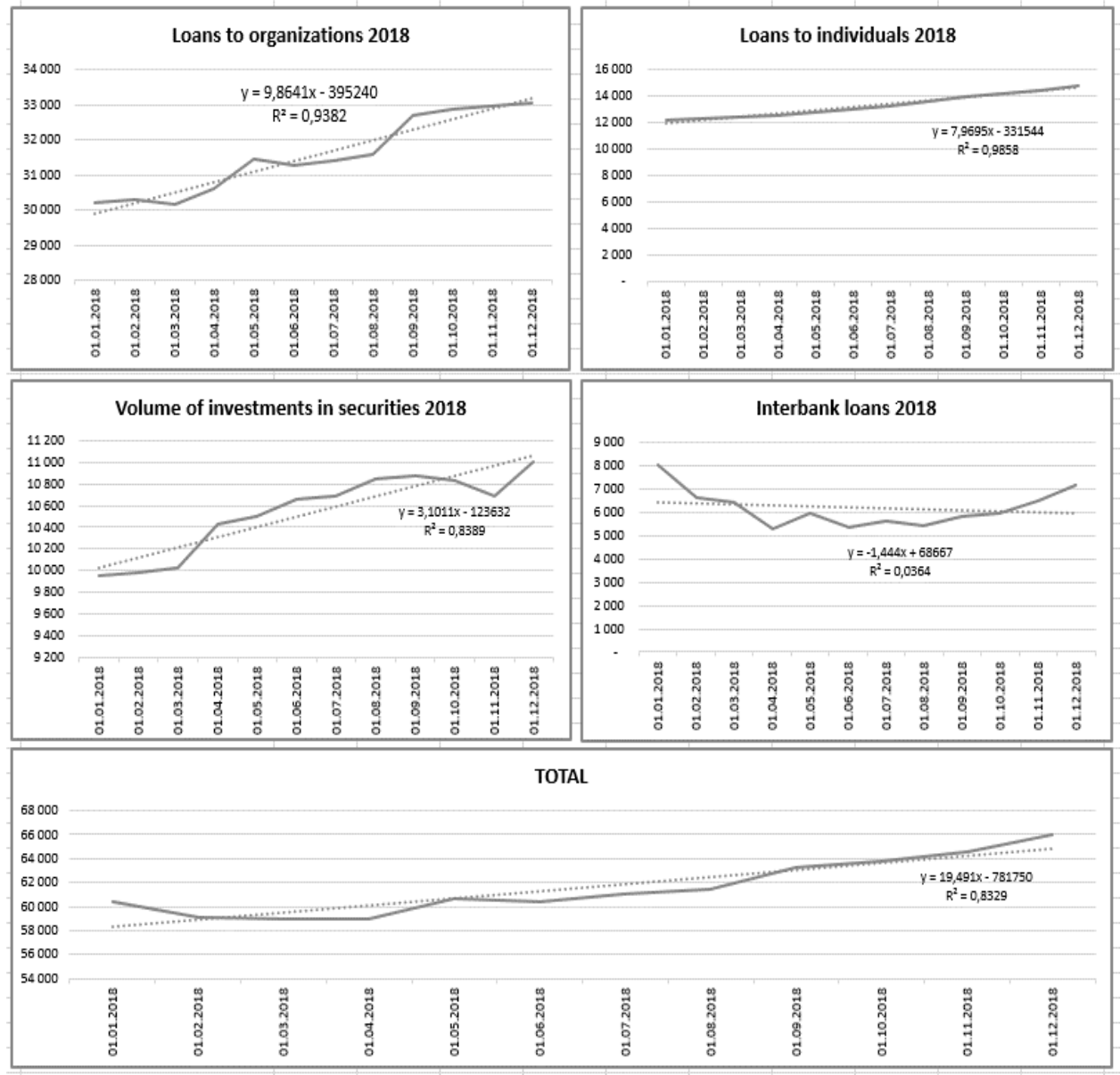

Fig. 6. Dynamics and linear trends in a number of indicators of banking institutions of the Russian Federation, 2018.

Next, we calculate the linear trend equation necessary for us to take into account the trends in the indicator in the reporting year and build points in a two-dimensional coordinate system in order to determine the structure of transaction services of the financial market of the Russian Federation in the modern period of the impact of external economic sanctions.

Table 7. Calculation of indicators Ki and Ti for model construction, 2018

\begin{tabular}{|c|c|c|c|c|c|}
\hline RecordlMonth & $\begin{array}{c}\text { Total average } \\
\text { for the year } \\
\text { with inflation } \\
\mathbf{8 . 8 \%} \text { trillion. } \\
\text { RUB }\end{array}$ & $\mathbf{A i}$ & $\begin{array}{c}\text { Coefficient } \\
\mathbf{A o}\end{array}$ & $\begin{array}{c}\mathbf{K i}=\mathbf{Y i} / \mathbf{Y 0} \\
* \mathbf{1 0 0} \% \\
\text { (abscissa) }\end{array}$ & $\begin{array}{c}\mathbf{T i}=\mathbf{A i} / \mathbf{A}_{\mathbf{0}} \text {. * } \\
\mathbf{1 0 0 \%} \text { (axis of } \\
\text { ordinates) }\end{array}$ \\
\hline $\begin{array}{c}\text { Loans to } \\
\text { organizations }\end{array}$ & 31554548 & 9,86 & 19,49 & 51,3 & 50,6 \\
\hline Loans to individuals & 13276412 & 7,97 & & 21,6 & 40,9 \\
\hline Interbank credit & 6189521 & $-1,44$ & & 10,1 & $-7,4$ \\
\hline $\begin{array}{c}\text { Volume of } \\
\text { investments in } \\
\text { securities }\end{array}$ & 10543652 & 3,10 & & 17,1 & 15,9 \\
\hline TOTAL & 61564133 & 19,49 & & 100,0 & 100,0 \\
\hline
\end{tabular}


Similar to the construction of the model for the previous two periods of 2008 and 2009 , we will make a graphical model for 2018.

We construct a model based on the obtained values of the parameters $\mathrm{Ki}$ and $\mathrm{Ti}$. The origin point is determined based on the average values of the Ki and Ti parameters. The volume of the ball in the figure will be equal to the average value of the indicator in the reporting period, also indicated in the data signature of each indicator in trillion. as a result, the resulting model will have the following form, shown in the figure

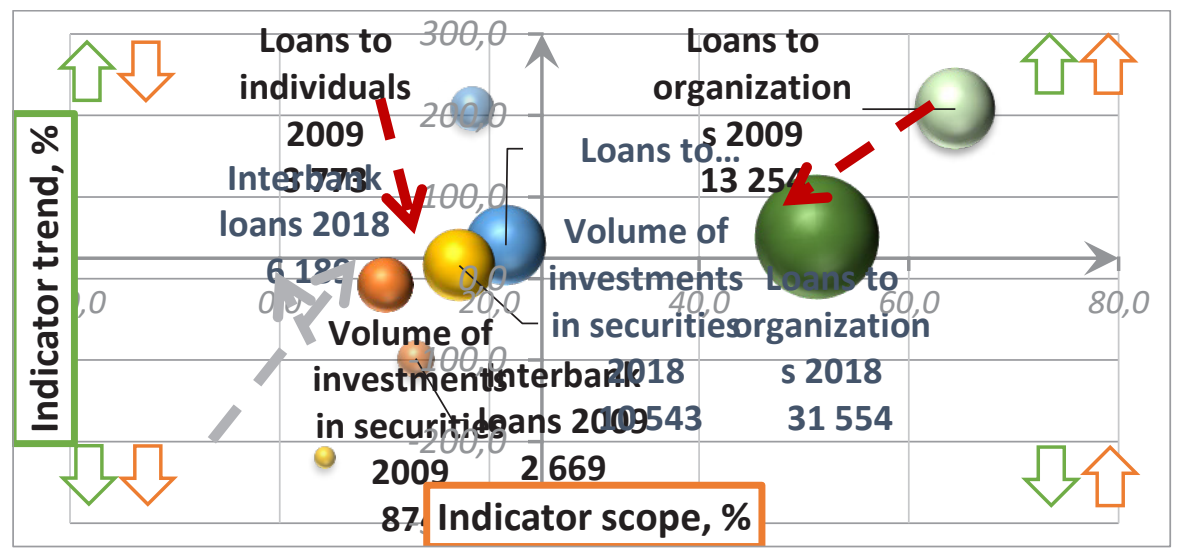

Fig. 7. Model for assessing the institutional impact of financial market institutions on economic growth, 2018.

Based on the results of the model, we see that in 2018 compared to 2009, the institutions of the financial sector of the Russian Federation moved from a state of "unstable economy" to a state of "economic growth".

\section{Research result}

According to the results of the study, it is possible to form a number of certain conclusions about the development of the financial sector of the Russian economy. The analysis of the activities of financial institutions showed that during the economic crisis of 2008-2009 and until 2018 in the country's economy there were a number of significant structural changes.

According to the results of the analysis of the period of influence of the global financial and economic crisis of 2008-2009 on the Russian economy, the financial sector of the country moved from the state of "inertial growth" to the state of "unstable economy".

Particularly interesting is the analysis of the financial sector in the modern period and the development of the Russian economy under the negative impact of external economic sanctions, which showed that in comparison with the situation in 2008-2009, the situation on the financial market in 2018 can be characterized as a state of "economic growth". According to the presented model, this economic growth in fact has some borderline state with the state of "inertial growth", however, it can be argued that the impact of economic sanctions on the Russian economy from other States is not so significant and does not lead to significant consequences in the form of a total deterioration of financial and economic indicators of the Russian financial market. 


\section{Conclusion}

The level of development of financial institutions has a significant impact on ensuring high rates and sustainability of economic growth.

The new institutional economic theory with the use of elements of mathematical modeling is currently able to act as a significant tool for monitoring and controlling the effectiveness of implementing institutional changes, or to act as an indicator indicating the need to implement institutional changes in a particular period of time [10].

The new system economic theory in systems research focuses on aspects related to the allocation of resources and the effectiveness of economic development.

In assessing the impact of financial institutions on economic growth, we note that the current analysis of financial institutions is based on a discrete analytical approach that takes into account only the quantitative characteristics of transactional financial services, and not the structural aspects, including the dynamics of this area of economic research, and that it is preferable to use the model to assess the institutional impact of financial institutions on economic growth.

Based on the proposed model, which assesses the institutional impact of financial institutions on economic growth, it is possible to characterize the state of the national financial system and analyze the trade sector of the economy. According to the calculation of the model, the following states of the national financial system should be distinguished: the state of economic growth; inertial development of the economy; economic instability; crisis economy or recession.

As a result of the research, we determine the state of financial institutions, the degree of their development, their interaction, the institutional environment in which they operate, and the structure of their ability to lend, invest, and sponsor certain projects.

The proposed model of assessing the institutional impact of financial institutions on economic growth can also be used to analyze the activities of financial institutions at the meso level, which will allow to regulate and make timely changes in the policy on the operational management of the financial market.

\section{References}

1. A. B. Ayurzanain, Economic sciences, 131, 7 (2015)

2. A. B. Ayurzanain, Economic Sciences, 73(12), 84 (2010)

3. S. E. Zhelaeva, A. B. Ayurzanain, O. A. Darmaeva, Russian Conference on Digital Economy and Knowledge Management, 523 (Atlantis Press, 2020)

4. D. C. North. Violence and social orders: A conceptual framework for interpreting recorded human history, 65 (Cambridge University Press, 2009)

5. A. E. Shastitko, I. P. Shabalov, I. N. Filippova, Economic Issues, 2, 74 (2018)

6. O. E. Williamson, E. Brousseau, J. M. Glachant, The New Institutional Economics Guidebook New Institutional Economics, 181 (2008)

7. R. H. Coase, Economics, 386 (1937)

8. G. M. Hodgson, Rethinking Economics, 59 (2017)

9. R. King, R. Levine, Quarterly Journal of Economics, 108 (1993) 